\title{
Osteoprotegerin mRNA is expressed in primary human osteoblast-like cells: down-regulation by glucocorticoids
}

\author{
N O A Vidal, H Brändström ${ }^{1}$, K B Jonsson ${ }^{1}$ and C Ohlsson \\ Research Centre for Endocrinology and Metabolism, Department of Internal Medicine, Sahlgrenska University Hospital, Gothenburg, Sweden and \\ ${ }^{1}$ Department of Internal Medicine, University of Uppsala, Uppsala, Sweden \\ (Requests for offprints should be addressed to C Ohlsson, Department of Internal Medicine, Division of Endocrinology, RCEM, Sahlgrenska Hospital, \\ S-41345 Göteborg, Sweden)
}

\begin{abstract}
Osteoprotegerin (OPG) is a recently cloned member of the tumour necrosis factor receptor family. It has been suggested that this secreted glycoprotein acts as an inhibitor of osteoclastic differentiation. Expression of OPG has previously been demonstrated in a number of tissues. However, it is still unclear whether or not OPG is expressed by human osteoblasts. We have used the RNase protection assay to demonstrate the OPG transcript in primary cultured human osteoblast-like cells, human marrow stroma cells and osteosarcoma cell lines. Furthermore, we have studied the effect of glucocorticoids on OPG mRNA levels in these cells. We demonstrate that glucocorticoids decrease the OPG transcript in a dose- and
\end{abstract}

time-dependent manner. The time-course study reveals that hydrocortisone $\left(10^{-6} \mathrm{M}\right)$ decreases OPG mRNA levels within $2 \mathrm{~h}$. This decrease is transient, reaching control levels again after $24 \mathrm{~h}$.

Our findings demonstrate that human osteoblasts express the mRNA corresponding to OPG, an inhibitor of osteoclast differentiation. The finding that OPG mRNA levels are decreased by glucocorticoids indicates that a reduced production of OPG from osteoblasts and/or marrow stroma cells could, in part, explain glucocorticoidinduced bone resorption.

Journal of Endocrinology (1998) 159, 191-195

\section{Introduction}

The regulation of bone metabolism results from a balance between bone resorption caused by osteoclasts and bone formation caused by osteoblasts. Imbalance in the remodelling process results in metabolic bone diseases such as osteoporosis. It appears that osteoblasts play a permissive role during the resorptive phase as it has been demonstrated that osteoclastic differentiation and activity requires the presence of osteoblastic cells (Takahashi et al. 1988, Martin \& Ng 1994, Jimi et al. 1996). Several studies have demonstrated that many factors which increase bone resorption, such as interleukin-6, parathyroid hormone and prostaglandin $\mathrm{E}_{2}$, regulate osteoclast differentiation indirectly via receptors on osteoblasts (Jilka 1986, Udagawa et al. 1995, Kaji et al. 1996). These observations indicate that osteoblasts, in addition to being directly responsible for bone formation, also control bone resorption by regulating the development of osteoclastic progenitor cells as well as the activity of mature osteoclasts.

Osteoporosis is a well known side-effect of long-term treatment with glucocorticoids (Canalis 1996). The mechanism responsible for glucocorticoid-induced osteoporosis is not fully understood but it has been demonstrated that high levels of glucocorticoids inhibit bone formation
(Canalis \& Avioli 1992, Delaney et al. 1994, Advani et al. 1997). The effect on bone resorption is unclear. Stimulatory (Tobias \& Chambers 1989, Dempster et al. 1997) as well as inhibitory (Conaway et al. 1996, Kaji et al. 1997) effects on osteoclast development and activity have been demonstrated in vitro, whereas in vivo more conclusive evidence for glucocorticoid-induced bone resorption exists (Bockman \& Weinerman 1990, Lowe et al. 1992).

Whereas the effect of glucocorticoids on bone formation is believed to be a direct effect on the osteoblast lineage, the effects of glucocorticoids on bone resorption are unclear and may involve direct effects on osteoclasts as well as secondary osteoblast-mediated effects.

Osteoprotegerin (OPG), also known as osteoclastogenesis-inhibitory factor, is a recently cloned member of the tumour necrosis factor (TNF) receptor family (Simonet et al. 1997, Tsuda et al. 1997). OPG is a soluble cytokine receptor which binds to the recently cloned OPG ligand (OPGL) (Lacey et al. 1998), also called osteoclast-differentiation factor (ODF) (Yasuda et al. 1998). Recombinant OPG inhibits osteoclast differentiation by binding to OPGL on the cell surface of marrow stroma cells and osteoblasts, thereby blocking the binding of OPGL to a putative membrane-bound TNF receptor member on osteoclasts (Yasuda et al. 1998). Recombinant 
OPG increases bone volume in bones from normal and ovariectomised rats. Furthermore, transgenic mice overexpressing OPG have increased bone density compared with normal litter mates (Simonet et al. 1997).

Because OPG could be a candidate factor in the local paracrine signalling between osteoblasts and osteoclasts in bone, we decided to study the expression of OPG mRNA in cultured human osteoblast-like (hOB) cells. We here demonstrate the novel findings that the OPG transcript is expressed by primary cultured hOB cells and that OPG mRNA levels are down-regulated by glucocorticoids.

\section{Materials and Methods}

\section{Cell culture}

Cultured hOB cells were isolated from cancellous bone from orthopaedic surgery as previously described (Nilsson et al. 1995). The bone explants were minced into small bone chips, extensively washed in DMEM/F12 1:1 (Gibco, Paisley, UK) and thereafter transferred into $162 \mathrm{~cm}^{2}$ culture flasks (Costar, Cambridge, MA, USA). The hOB cells and osteosarcoma cell lines MG-63 and SaOS-2 were cultured in DMEM/F12, 1:1 with the addition of $10 \%$ fetal calf serum (FCS; Gibco), Fungizone $(500 \mu \mathrm{g} / \mathrm{l}$; Gibco), gentamycin sulphate $(50 \mathrm{mg} / \mathrm{l}$; Sigma, St Louis, MO, USA), L-glutamine (2 mmol/l; Gibco) and L-ascorbic acid $(100 \mathrm{mg} / \mathrm{l}$; Merck, KGaA, Darmstadt, Germany), in a humidified $5 \% \mathrm{CO}_{2}$ atmosphere at $37^{\circ} \mathrm{C}$. Human marrow stroma cells (hMS) were isolated as follows. Bone fragments were rinsed with PBS and bone marrow cells were collected and centrifuged through a column of histopaque 1077. Cells from the interface were pelleted, counted and seeded into $75 \mathrm{~cm}^{2}$ culture flasks. The cells were incubated in a humidified $\mathrm{CO}_{2}$ incubator at $37^{\circ} \mathrm{C}$ and the medium was changed weekly. At confluence, cells were detached with trypsin-EDTA $(0 \cdot 05 / 0 \cdot 02 \% \mathrm{w} / \mathrm{v})$ and subcultured in $75 \mathrm{~cm}^{2}$ flasks containing $\alpha$-MEM supplemented with 10\% FCS and antibiotics $(100 \mathrm{U} / \mathrm{ml}$ of penicillin, $100 \mathrm{mg} / \mathrm{ml}$ streptomycin, amphotericin-B, L-glutamine $(2 \mathrm{mM})$ ) and FCS $(10 \%)$. Only first passage cells were used in the experiments.

When the effect of glucocorticoids, testosterone or oestrogen was tested, hOB cells and MG-63 cells were starved in DMEM without phenol red (Gibco) (in order to avoid oestrogen-like effects of phenol red) with the addition of $0.5 \%$ dextran-coated charcoal-stripped FCS (DCC-FCS; kindly provided by Dr M Slootweg, The Netherlands) for a period of $48 \mathrm{~h}$ during which hydrocortisone (H-0135, Lot: 44H9402, 115H4629, Sigma) was added at intervals ranging from 24 to $47 \cdot 5 \mathrm{~h}$. All cultures were harvested after $48 \mathrm{~h}$. Dose dependence was studied in a similar manner, including starvation for $24 \mathrm{~h}$, followed by the addition of glucocorticoids at final concentrations ranging from $10^{-9}$ to $10^{-6} \mathrm{M}$ (hOB and MG-
63 hydrocortisone, hMS, dexamethasone, Sigma). The cultures were harvested after $8 \mathrm{~h}$. Hydrocortisone was dissolved in absolute ethanol and diluted 1:1000 in the culture medium. Testosterone (Sigma, T-1500) and oestrogen ( $\beta$-oestradiol, Sigma, E-2758, Lot: 38F-07655) were dissolved and diluted as described for hydrocortisone above.

The study was approved by the ethical committee at Sahlgrenska University Hospital in Gothenburg.

\section{Probes}

A 219 bp (nucleotides 496-714) cDNA fragment, part of the full-length human OPG cDNA (genebank U94332), was generated with reverse transcriptase PCR and total RNA from hOB cells, using the following primer pairs: 5'-AACCCCAGAGCGAAATAC- $3^{\prime}$ and 5'-AAGAAT GCCTCCTCACAC- $3^{\prime}$. The cDNA fragment was inserted into a PCR-II vector (Invitrogen, Leek, The Netherlands) by T/A-cloning and the sequence was verified by sequencing. The vector was linearised with HindIII prior to in vitro transcription with SP6-polymerase in the presence of $\left.{ }^{33} \mathrm{P}\right] \alpha \mathrm{UTP}$. The $85 \mathrm{bp}$ human ribosomal $18 \mathrm{~S}$ internal standard (Ambion, Austin, TX, USA) was linearised with HindIII and T7-polymerase was used for in vitro transcription and incorporation of $\left[{ }^{33} \mathrm{P}\right] \alpha \mathrm{UTP}$ (hOB and MG-63). Alternatively, the $154 \mathrm{bp}$ glyceraldehyde phosphate dehydrogenase internal standard (Ambion), linearised by $\mathrm{XbaI}$ and transcribed with $\mathrm{T} 3$ polymerase, was used (hMS).

\section{RNase protection assay}

RNA was prepared as described elsewhere (Chomczynski \& Sacchi 1987). The OPG transcripts were quantified with an RNase protection assay (RPA II kit, Ambion). Total cellular RNA $(10 \mu \mathrm{g})$ was hybridised at $45^{\circ} \mathrm{C}$ overnight with $\left[{ }^{33} \mathrm{P}\right] \alpha \mathrm{UTP}$-labelled human OPG riboprobe and $18 \mathrm{~S}$ internal standard, then digested with RNase. The RNA/RNA hybrids were precipitated, resuspended and separated on a $6 \% \mathrm{TBE}$ (tris-borate (90 mM)-EDTA (2 mM))-urea gel. The protected fragments were visualised and quantified using a PhosphorImager (Molecular Dynamics, Sunnyvale, CA, USA).

\section{Results}

First we wanted to investigate if the OPG transcript is expressed in primary cultured hOB cells. The RNase protection assay demonstrated that the OPG transcript was expressed in hOB cells and in the mineralising human osteosarcoma cell line SaOS-2 (Fig. 1). Furthermore, the OPG transcript was highly expressed in the nonmineralising osteosarcoma cell line MG-63 (Fig. 1). Levels in MG-63 cells were $198 \pm 5 \%$ over SaOS-2 levels $(n=3)$. 
A

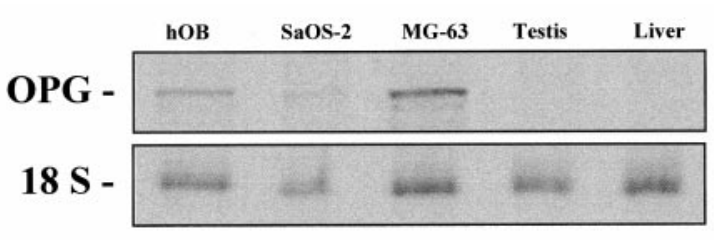

B

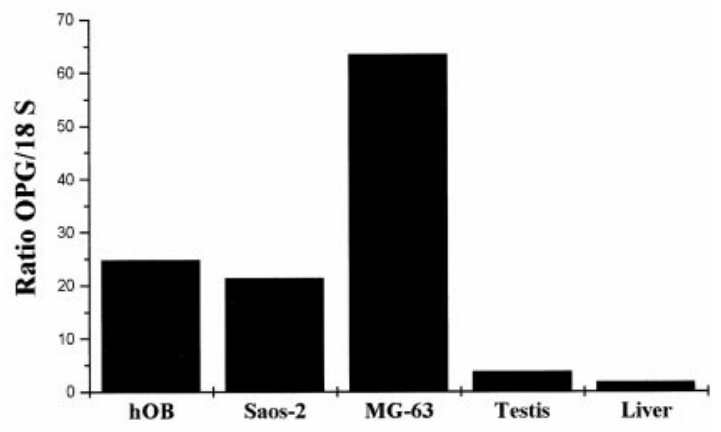

C

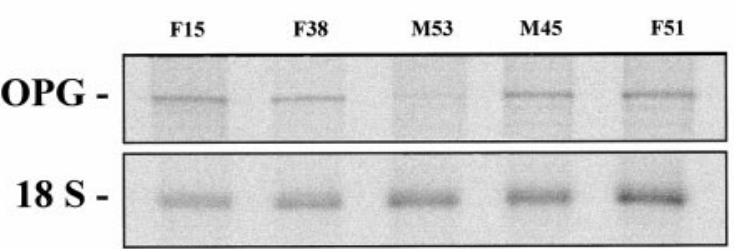

Figure 1 Expression of OPG mRNA levels in human osteoblasts (hOB), two osteosarcoma cell lines (MG-63 and SaOS-2) and in human liver and testis. (A) RNase protection assay and (B) the mean OPG/18S ratios of two separate RNA-samples from one patient (testis and liver) or from two separate cell cultures (hOB, MG-63 and SaOS-2). (C) RNase protection assay of OPG expression in hOB preparations from five different patients ( $\mathrm{F} 15=$ female, 15 years old; $\mathrm{F} 38=$ female, 38 years old; $\mathrm{M} 53=$ male, 53 years old; $M 45=$ male, 45 years old, $F 51=$ female, 51 years old).

We studied the OPG mRNA levels in hOB cell preparations from eight different cell donors (six females and two males, $15-58$ years old) and detected OPG mRNA in all but one of these cell preparations. We could not find any correlation between OPG mRNA levels and cell density (data not shown).

The next question was to study if glucocorticoids regulate OPG mRNA levels. Hydrocortisone decreased the levels of OPG mRNA in hOB cells in a dose-dependent manner (Fig. 2). Treatment of MG-63 cells with hydrocortisone $\left(10^{-6} \mathrm{M}\right)$ and hMS cells with dexamethasone $\left(10^{-6} \mathrm{M}\right)$ for $8 \mathrm{~h}$ resulted in a similar decrease in OPG mRNA levels (Fig. 2A and B). Time-course studies (Fig. 3) revealed that hydrocortisone $\left(10^{-6} \mathrm{M}\right)$ decreased OPG mRNA levels in hOB cells within $2 \mathrm{~h}$ (72 $\pm 4 \%$ of control culture) and that this decrease was present $8 \mathrm{~h}$ (58 $\pm 8 \%$ of control culture) after
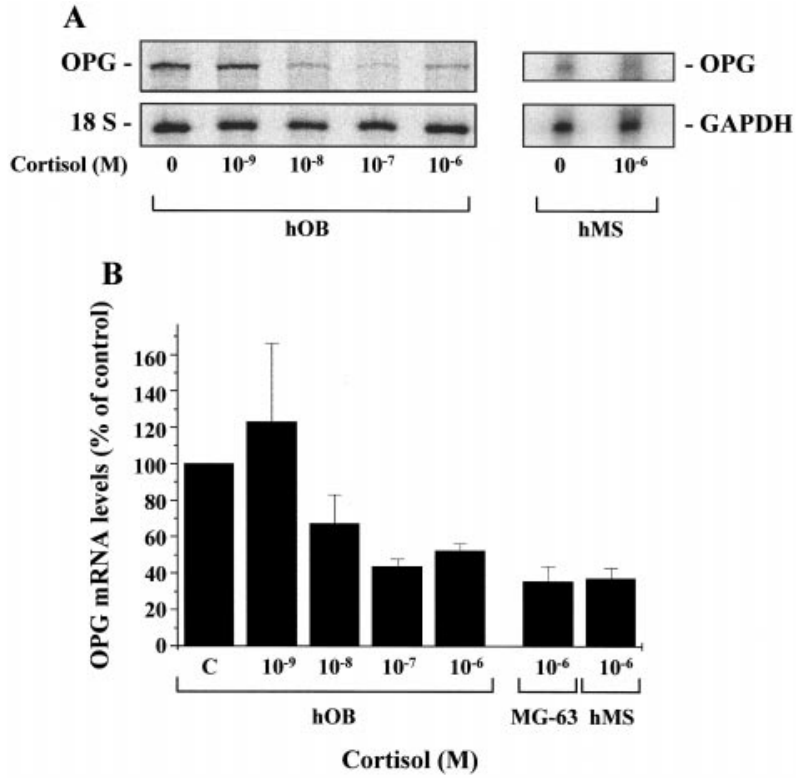

Figure 2 Dose-response effect of glucocorticoids on OPG mRNA levels in cultured human osteoblasts ( $\mathrm{hOB}$, hydrocortisone), human marrow stroma cells (hMS, dexamethasone) and the osteosarcoma cell line MG-63 (hydrocortisone). Cells were cultured in $10 \%$ FCS, starved in DMEM without phenol red with addition of $0 \cdot 5 \%$ DCC-FCS for $24 \mathrm{~h}$ and then stimulated with different doses of glucocorticoids $8 \mathrm{~h}$ before harvest. Each experiment was performed using cells from one patient.

(A) Representative RNase protection assay gel picture.

(B) Densitometric quantification of the results from hOB-cells from three different patients, three cultures of MG-63 cells and two separate hMS cell cultures. Values are expressed as OPG mRNA as per cent of control \pm S.E.M.

hydrocortisone stimulation. Control levels were reached again after $24 \mathrm{~h}(109 \pm 13 \%$ of control culture).

The effects of testosterone $\left(10^{-12}\right.$ to $\left.10^{-8} \mathrm{M}\right)$ and oestrogen $\left(10^{-15}\right.$ to $\left.10^{-8} \mathrm{M}\right)$ were also studied under similar culture conditions, but no statistically significant effects were found (data not shown).

\section{Discussion}

Osteoclast differentiation is regulated by many hormones and growth factors (Suda et al. 1992, 1995, Lerner \& Ohlin 1993, Hofbauer \& Heufelder 1996, Lerner 1996). It is generally believed that the presence of osteoblastic cells is required for normal osteoclast development (Takahashi et al. 1988, Martin \& Ng 1994, Jimi et al. 1996). We here report the novel finding that the OPG transcript is expressed in primary cultured hOB cells. This finding strongly suggests that local production of OPG may be of importance for the coupling between osteoblasts and osteoclast development in human bone tissue.

Previously presented in vitro and in vivo results, on the effects of OPG in rodents, indicate that the main effect of 


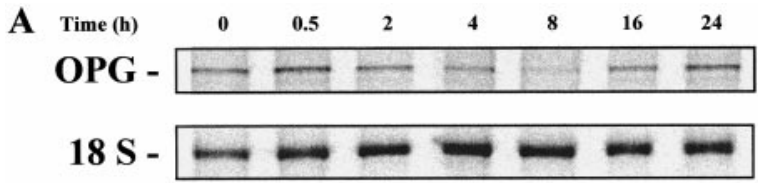

B



Figure 3 Time-course effect of hydrocortisone on OPG mRNA levels in hOB cells. Cells were cultured in 10\% FCS, then starved in DMEM without phenol red with addition of 0.5\% DCC-FCS for a total length of $48 \mathrm{~h}$ and stimulated with hydrocortisone $\left(10^{-6} \mathrm{M}\right)$ at different times before harvest. (A) RNase protection assay of hOB from a 53-year-old male. (B) Densitometric quantification of the pooled results from three experiments. Each experiment was performed using cells from one patient. The results from three different patients were then pooled and are shown in (B). Values are expressed as OPG/18S ratio as per cent of control \pm S.E.M. ${ }^{*} P<0.05$ compared with untreated cells.

OPG is to inhibit the differentiation of osteoclasts. Glucocorticoid-induced bone resorption could therefore, in part, result from a local down-regulation of OPG expression in bone. This notion is supported by recent findings that high levels of glucocorticoids increase osteoclast recruitment rather than activity in mouse bone and spleen cultures (Kaji et al. 1997) and by the finding that the effect of glucocorticoids on resorption is dependent on cellular replication in neonatal mouse calvariae (Conaway et al. 1996). We therefore chose to investigate the effects of glucocorticoids on osteoblastic expression of OPG mRNA. Our results clearly demonstrate that glucocorticoids decrease the OPG transcript in hOB cells and in human marrow stroma cells. Other steroids with welldocumented effects on bone metabolism, such as testosterone and oestrogen, did not cause a change in OPG mRNA levels under similar culture conditions, demonstrating that the effect of glucocorticoids is specific. Our finding that glucocorticoids decrease the OPG transcript is intriguing, not only because it provides a possible explanation of how glucocorticoids may influence bone resorption, but also because it indicates that the local cross-talk taking place between osteoblasts and osteoclasts in bone may be of either a stimulatory or inhibitory nature. This notion is clearly supported by recent reports that OPGL or
ODF, the membrane-bound ligand for OPG (Lacey et al. 1998, Yasuda et al. 1998), is present on marrow stroma cells and osteoblasts (Yasuda et al. 1998). The finding that osteoblasts produce OPG as well as ODF is evidence for a negative feed-back loop in which the osteoblast itself may modulate the recruitment of osteoclast precursors by presenting ODF molecules on its surface, which in turn can be made unavailable by systemic or locally produced OPG.

It is interesting to note that the mineralising osteosarcoma cell line SaOS-2 together with hOB cells expressed significantly lower amounts of OPG transcript when compared with the non-mineralising osteosarcoma cell line MG-63. This finding indicates that the OPG transcript could be differentially regulated during osteoblast differentiation. However, in the present study we failed to detect any significant alterations of OPG mRNA levels in hOB cells at different stages of confluence.

In conclusion we have, for the first time, demonstrated that the OPG transcript is expressed in primary cultured hOB cells and in hMS cells. Furthermore, OPG mRNA levels were shown to be decreased by glucocorticoids in these cells. Our findings indicate that glucocorticoidinduced bone resorption in part may result from a decrease in the local secretion of OPG from osteoblasts/marrow stroma cells. The biological significance of this finding remains to be demonstrated and will remain unresolved until commercial antibodies for OPG are made available.

\section{Acknowledgements}

This work was supported by grants K95-19P-11328-01A and K96-19P11837-02B from the Swedish Medical Research Council, grants from Pharmacia \& Upjohn (Stockholm, Sweden), the Novo Nordisk Foundation (Bagsvaerd, Denmark), the Lundberg Foundation, and the Göteborg Medical Society. We thank A Hansevi for her excellent assistance. We would also like to thank the Department of Orthopaedics, Sahlgrenska Hospital, and Dr Anders Nilsson for providing us with bone samples.

\section{References}

Advani S, LaFrancis D, Bogdanovic E, Taxel P, Raisz LG \& Kream BE 1997 Dexamethasone suppresses in vivo levels of bone collagen synthesis in neonatal mice. Bone 20 41-46.

Bockman RS \& Weinerman SA 1990 Steroid-induced osteoporosis. Orthopedic Clinics of North America 21 97-107.

Canalis E 1996 Mechanisms of glucocorticoid action in bone: implications to glucocorticoid-induced osteoporosis. Journal of Endocrinology and Metabolism 81 3441-3447.

Canalis E \& Avioli L 1992 Effects of deflazacort on aspects of bone formation in cultures of intact calvariae and osteoblast-enriched cells. Journal of Bone and Mineral Research 7 1085-1092.

Chomczynski P \& Sacchi N 1987 Single-step method of RNA isolation by acid guanidinium thiocyanate-phenol-chloroform extraction. Analytical Biochemistry 162 156-159. 
Conaway HH, Grigorie D \& Lerner UH 1996 Stimulation of neonatal mouse calvarial bone resorption by the glucocorticoids hydrocortisone and dexamethasone. Journal of Bone and Mineral Research 11 1419-1429.

Delaney AM, Dong Y \& Canalis E 1994 Mechanisms of glucocorticoid action in bone cells. Journal of Biochemistry $\mathbf{5 6}$ 295-302.

Dempster DW, Moonga BS, Stein LS, Horbert WR \& Antakly T 1997 Glucocorticoids inhibit bone resorption by isolated rat osteoclasts by enhancing apoptosis. Journal of Endocrinology 154 397-406.

Hofbauer LC \& Heufelder AE 1996 Intercellular chatter: osteoblasts, osteoclasts and interleukin 6. European Journal of Endocrinology 134 425-426.

Jilka RL 1986 Are osteoblastic cells required for the control of osteoclast activity by parathyroid hormone? Journal of Bone and Mineral Research 1 261-266.

Jimi E, Nakamura I, Amano H, Taguchi Y, Tsurukai T, Tamura M, Takahashi N \& Suda T 1996 Osteoclast function is activated by osteoblastic cells through a mechanism involving cell-to-cell contact. Endocrinology 137 2187-2190.

Kaji H, Sugimoto T, Kanatani M, Fukase M, Kumegawa M \& Chihara K 1996 Prostaglandin E2 stimulates osteoclast-like cell formation and bone-resorbing activity via osteoblasts: role of cAMP-dependent protein kinase. Journal of Bone and Mineral Research 11 62-71.

Kaji H, Sugimoto T, Kanatani M, Nishiyama K \& Chihara K 1997 Dexamethasone stimulates osteoclast-like cell formation by directly acting on hemopoietic blast cells and enhances osteoclast-like cell formation stimulated by parathyroid hormone and prostaglandin $\mathrm{E}_{2}$. Journal of Bone and Mineral Research 12 734-741.

Lacey DL, Timms E, Tan HL, Kelley MJ, Dunstan CR, Burgess T, Elliott R, Colombero A, Elliott G, Scully S, Hsu H, Sullivan J, Hawkins N, Davy E, Caparelli C, Eli A, Qian YX, Kaufman S, Sarosi I, Shalhoub V, Senaldi G, Guo J, Delaney J \& Boyle WJ 1998 Osteoprotegerin ligand is a cytokine that regulates osteoclast differentiation and activation. Cell 93 165-176.

Lerner UH 1996 Transforming growth factor- $\beta$ stimulates bone resorption in neonatal calvariae by a prostaglandin-unrelated but cell proliferation-dependent pathway. Journal of Bone and Mineral Research 11 1628-1639.

Lerner UH \& Ohlin A 1993 Tumor necrosis factors alpha and beta can stimulate bone resorption in cultured mouse calvariae by a prostaglandin-independent mechanism. Journal of Bone and Mineral Research 8 147-155.

Lowe C, Gray DH \& Reid IR 1992 Serum blocks the osteolytic effect of cortisol in neonatal mouse calvaria. Calcified Tissue International 50 189-192.
Martin TJ \& Ng KW 1994 Mechanisms by which cells of the osteoblast lineage control osteoclast formation and activity. Journal of Cellular Biochemistry 56 357-366.

Nilsson A, Swolin D, Enerbäck S \& Ohlsson C 1995 Expression of functional growth hormone receptors in cultured human osteoblast-like cells. Journal of Clinical Endocrinology and Metabolism $803483-3488$.

Simonet WS, Lacey DL, Dunstan CR, Kelley M, Chang MS, Lüthy R, Nguyen HQ, Wooden S, Bennett L, Boone T, Shimamoto G, DeRose M, Elliott R, Colombero A, Tan HL, Trail G, Sullivan J, Davy E, Bucay N, Renshaw-Gegg L, Hughes TM, Hill D, Pattison W, Campbell P, Sander S, Van G, Tarpley J, Derby P, Lee R, Amgen EST Program \& Boyle WJ 1997 Osteoprotegerin: a novel secreted protein involved in the regulation of bone density. Cell 89 309-319.

Suda T, Takahashi N \& Abe E 1992 Role of vitamin D in bone resorption. Journal of Biochemistry 49 53-58.

Suda T, Udagawa N, Nakamura I, Miyaura C \& Takahashi N 1995 Modulation of osteoclast differentiation by local factors. Bone $\mathbf{1 7}$ 87S-91S

Takahashi N, Akatsu T, Udagawa N, Sasaki T, Yamaguchi A, Moseley JM \& Suda T 1988 Osteoblastic cells are involved in osteoclast formation. Endocrinology 123 2600-2602.

Tobias J \& Chambers TJ 1989 Glucocorticoids impair bone resorptive activity and viability of osteoclasts disaggregated from neonatal rat long bones. Endocrinology 125 1290-1295.

Tsuda E, Goto M, Mochizuki S, Yano K, Kobayashi F, Morinaga T \& Higashio K 1997 Isolation of a novel cytokine from human fibroblasts that specifically inhibits osteoclastogenesis. Biochemical and Biophysical Research Communications 234 137-142.

Udagawa N, Takahashi N, Katagiri T, Tamura T, Wada S \& Findlay DM 1995 Interleukin-6 induction of osteoclast differentiation depends on IL-6 receptors expressed on osteoblastic cells but not on osteoclast progenitors. Journal of Experimental Medicine $\mathbf{1 8 2}$ 1461-1468.

Yasuda H, Shima N, Nakagawa N, Yamaguchi K, Kinosaki M, Mochizuki S, Tomoyasu A, Yano K, Goto M, Murakami A, Tsuda E, Morinaga T, Higashio K, Udagawa N, Takahashi N \& Suda T 1998 Osteoclast differentiation factor is a ligand for osteoprotegerin/osteoclastogenesis-inhibitory factor and is identical to TRANCE/RANKL. Proceedings of the National Academy of Sciences of the USA 95 3597-3602.

Received 2 March 1998

Revised manuscript received 5 May 1998

Accepted 29 May 1998 